\title{
Editorial
}

\section{The French Tax System Challenged by Economic Globalisation}

Delphine de Drouâs, Attorney-at-Law, Coopers \& Lybrand CLC Juridique et Fiscal, Paris

\section{Introduction}

Companies are permanently striving to be more competitive. Governments faced with the globalisation of the economy must also be competitive if they wish to continue to attract quality investments and people. This requirement is naturally increased by the Single European Market and the limited scope of the harmonisation of tax rates. Therefore, the competitiveness of tax systems is certainly one of the key elements for tomorrow's economic growth.

These remarks need to be constantly kept in mind when considering the new French tax developments. At the French Ministry of Finance, the approach to the necessity for globalisation has been what could be qualified as sporadic. Fortunately, pragmatism and economic logic have successfully overcome the political and budget constraints in some of the most recent tax projects.

\section{Necessity for More Pragmatism in the French Tax Policy}

Recent developments show the absolute necessity for more pragmatism. During 1996, taxpayers in the top tax band either left or intended to leave France because of the reform of the wealth tax. Until 1995, the wealth tax added to personal income tax was limited to 85 per cent of personal taxable income, but this limitation has been partly eliminated by the 1996 Finance Act. Consequently, certain companies, mainly family businesses, now have shareholders unable to pay their wealth tax with the income from their shareholdings. Only certain qualified company officers can escape wealth tax on their shareholdings, subject to various conditions. According to the National Assembly reporter of the Finance Commission, 400 taxpayers are concerned by the new measure. While from a political viewpoint this is a small number, from an economic point of view it is strategic.

At the government stage of the 1996 Finance Bill, the risks of tax evasion through expatriation (tax delocalisation) were not addressed, and only the intention to increase the wealth tax on a slim minority of taxpayers was evoked. At the parliamentary stage, the risks of this delocalisation for the taxpayers who will have to pay more than 100 per cent of their income in taxes were clearly pointed out during the National Assembly and Senate debates.

It is also well known that London has attracted many French 'golden boys' in the banking sector, motivated by Britain's personal income tax regime.

\section{Progress to Date}

One of the last important measures improving French tax competitiveness was granted in 1988. The possibility of opting for a tax consolidated group was a major reform in the French taxation system, despite a few imperfections at the beginning. Until 1988, the concept of tax unit did not exist for corporate tax purposes, and French group companies could have to pay corporate income tax, even though the French group overall was in a position of loss.

New measures are currently foreseen for both companies and individuals.

The 1997 Finance Bill provides for the gradual decrease over several years (1996 to 2000) of progressive rates of personal income tax. In particular, the highest personal income tax rate should be lowered from the present 56.8 per cent to 47 per cent in 2000 . A plan to create French pension funds for which a tax deduction would be granted is also foreseen. This project aims to limit the drop in the value of pensions and consolidating French companies' net worth. Equivalent decreases in public expenditure would certainly strengthen the viability and the durability of the tax cuts.

With regard to companies, last summer the French Government promised an important 
reform for multinational companies intragroup services: the extension of the French headquarters regime. The specific regime (basically secured cost plus transfer prices and personnel income tax incentives for expatriates) would be extended in four directions: (1) extension to French groups (it is currently limited to international groups); (2) elimination of any geographical limitations for the headquarters' activities; (3) extension to banking and financing activities; and (4) extension to distribution centres. The idea behind this reform is to compete with other European countries through a better and safer tax regime.

\section{Future Aims}

The expectations of companies are still high in many fields, such as the high registration duties on business transfers, the non-deductibility of goodwill amortisation, the reform of the business licence tax, a more accurate transposition of European Union directives, and, more generally, the too-limited scope of the French ruling procedure.

In its 13th report of 1994, the French Tax Commission (Conseil des Impôts) recommended the progressive adaptation and extension of the ruling procedures, rather than a radical reform. This recommendation has been followed too literally and a ruling procedure has been introduced by a law of 12 April 1996. This ruling procedure is very innovative, given the French administrative practice's traditionally reluctant attitude towards rulings. The new ruling procedure looks at the way facts are evaluated with regard to only two specific tax regimes: the corporate tax exemption for new businesses, and certain exceptional amortisation regimes. The most innovative aspect is that the silence of the French tax authorities after a three-month period is deemed an acceptance. In other words, no reassessment can then be notified by the tax authorities concerning the situation described.

A wider reform, perhaps a radical one, is still hoped for. Ruling procedures with a wider scope, covering any tax issue with a regular publication of the rulings rendered, would ease relations with the tax authorities, reduce the number of litigation proceedings, and increase the transparency of and confidence in the French administration. Many companies have known radical changes in recent years. A modern economy also supposes a modern and flexible administration. 